\title{
Naghmeh Mahzounzadeh, Eugenio Bortolini. "Beyond Shape: a New Perspective on the Classification of Arrowheads from the Historical Pre-Islamic Period in Iran"
}

\section{Luca Colliva}

\section{(2) OpenEdition}

\section{Journals}

Electronic version

URL: https://journals.openedition.org/abstractairanica/51768

DOI: $10.4000 / a b s t r a c t a i r a n i c a .51768$

ISSN: 1961-960X

Publisher:

CNRS (UMR 7528 Mondes iraniens et indiens), Éditions de l'IFRI

Electronic reference

Luca Colliva, "Naghmeh Mahzounzadeh, Eugenio Bortolini. "Beyond Shape: a New Perspective on the Classification of Arrowheads from the Historical Pre-Islamic Period in Iran"', Abstracta Iranica [Online], Volume 42-43 | 2021, document 10, Online since 30 December 2020, connection on 14 December 2022. URL: http://journals.openedition.org/abstractairanica/51768 ; DOI: https://doi.org/10.4000/ abstractairanica. 51768

This text was automatically generated on 14 December 2022.

All rights reserved 


\title{
Naghmeh Mahzounzadeh, Eugenio Bortolini. "Beyond Shape: a New Perspective on the Classification of Arrowheads from the Historical Pre- Islamic Period in Iran"
}

\author{
Luca Colliva
}

\section{REFERENCES}

Naghmeh Mahzounzadeh, Eugenio Bortolini. "Beyond Shape: a New Perspective on the Classification of Arrowheads from the Historical Pre-Islamic Period in Iran", East \& West n.s. $1 / 2,2020$, p. $285-300$

1 The article, published in the first number of the new series of East \& West journal edited by ISMEO, proposes an innovative methodology, based on pattern recognition techniques, for the study of the metal arrowheads, and a new typology mainly focused on materials dated between the 6 th and 4 th century BCE.

2 The authors propose a first pilot study, part of a larger project still underway, in which 167 arrowheads from the sites of Persepolis, Tol-e Ajori and Susa are taken into consideration. Each artefact has been described through twenty-four characters, ten quantitative and fourteen qualitative. A hierarchical cluster analysis of the collected data was subsequently performed and compared against a grouping obtained through k-medoid clustering. The procedure led to the identification of a two-level structure with two main groups, copper alloy and iron arrowheads, divided into a total of eight subgroups based on the supporting system of the base and the number, shape and cross-section of blades. Moreover, a group of idiosyncratic arrowheads was recognised as an outgroup. The results obtained from the data analysis, although preliminary, also 
provide novel interesting insights for the evaluation of the identified morphological features.

\section{AUTHORS}

\section{LUCA COLLIVA}

Alma Mater Studiorum - Università di Bologna 